\title{
The Porphyromonas gingivalis inhibitory effects, antioxidant effects and the safety of a Sri Lankan traditional betel quid - an in vitro study
}

Madhavi Priyanka Paranagama ${ }^{1 *}$ (D, Nadisha Sewwandi Piyarathne ${ }^{1}$, Tharanga Lakmali Nandasena', Sumedha Jayatilake ${ }^{2}$, Ayanthi Navaratne ${ }^{3}$, Bandula Prasanna Galhena ${ }^{4}$, Senani Williams ${ }^{5}$, Jayantha Rajapakse ${ }^{6}$ and Kiyoshi $\mathrm{Kita}^{7}$

\begin{abstract}
Background: The Sri Lankan traditional betel quid (TBQ) which had been extensively used in the country before its colonization is claimed to have antiperiodontopathic effects in the Sri Lankan folklore. However, there is no reported scientific evidence to support the claimed antiperiodontopathic effects mediated by this TBQ. The present study was carried out to investigate the protective effect of the Sri Lankan TBQ in the pathogenesis of periodontitis.

Methods: We investigate the ethyl acetate extract of the Sri Lankan TBQ for its antibacterial effects against the keystone periodontopathic bacterium, $P$. gingivalis and also its antioxidant potential, which is important to protect the periodontium from oxidative stress. Further, its safety was analyzed using the cytokinesis block micronucleus assay on human peripheral blood lymphocytes (PBLs).

Results: Ethyl acetate extract of this TBQ inhibited the growth of $P$. gingivalis with a minimum bactericidal concentration (MBC) of $125 \mu \mathrm{g} / \mathrm{ml}$. It was found to be a rich source of polyphenols and displayed considerable DPPH and ABTS radical scavenging activities and a strong ferric reducing antioxidant power. This extract could protect the cultured human gingival fibroblasts from $\mathrm{H}_{2} \mathrm{O}_{2}$ induced oxidative stress. In addition, this TBQ extract was not genotoxic to human PBLs even at a concentration of $2.5 \mathrm{mg} / \mathrm{ml}$. Moreover, it exhibited protective effects against bleomycin induced genotoxicity in PBLs.
\end{abstract}

Conclusion: Ethyl acetate extract of the Sri Lankan TBQ is a source of natural antibacterial compounds against $P$. gingivalis. It is also a source of natural antioxidants which can protect human gingival fibroblasts from $\mathrm{H}_{2} \mathrm{O}_{2}$ induced oxidative stress. These properties of the TBQ may have contributed to its claimed antiperiodontopathic effects. Besides, it was found to be relatively non-toxic to human cells. Thus this TBQ extract has a huge potential to be developed as a novel adjunctive therapeutic lead against periodontitis.

Keywords: Sri Lankan traditional betel quid, Chronic periodontitis, P. gingivalis, Oxidative stress, Genotoxicity, Cytotoxicity, MTT assay, CBMN assay

\footnotetext{
*Correspondence: madhaviparanagama@gmail.com

'Department of Basic Sciences, Faculty of Dental Sciences, University of Peradeniya, Peradeniya, Sri Lanka

Full list of author information is available at the end of the article
}

(c) The Author(s). 2020 Open Access This article is licensed under a Creative Commons Attribution 4.0 International License, which permits use, sharing, adaptation, distribution and reproduction in any medium or format, as long as you give appropriate credit to the original author(s) and the source, provide a link to the Creative Commons licence, and indicate if changes were made. The images or other third party material in this article are included in the article's Creative Commons licence, unless indicated otherwise in a credit line to the material. If material is not included in the article's Creative Commons licence and your intended use is not permitted by statutory regulation or exceeds the permitted use, you will need to obtain permission directly from the copyright holder. To view a copy of this licence, visit http://creativecommons.org/licenses/by/4.0/ The Creative Commons Public Domain Dedication waiver (http://creativecommons.org/publicdomain/zero/1.0/) applies to the data made available in this article, unless otherwise stated in a credit line to the data. 


\section{Background}

Periodontitis, which is identified as the sixth most common infectious disease in the world, is characterized by destruction of the periodontal tissues including gingiva, periodontal ligament and the alveolar bone with eventual loss of teeth $[1,2]$. Several lines of evidence indicate that periodontitis not only affects the oral health, but also the general health of an individual since it is associated with other systemic conditions such as cardiovascular diseases, diabetes mellitus, rheumatoid arthritis, respiratory diseases, and preterm low birth weights [3-7]. Thus, this disease imposes a strong negative impact on the overall wellbeing of the affected individuals and the economy of a country.

Periodontitis is caused by periodontopathic bacteria in the subgingival biofilms [8]. The gram negative anaerobic bacterium Porphyromonas gingivalis is identified as the keystone bacterium in the development of this disease $[9,10]$. However, the presence of periodontopathic bacteria alone is not sufficient for development of the disease. A complex interplay between the periodontopathic bacteria and the host immune system is essential for the initiation and progression of periodontitis [11, 12]. In response to periodontopathic bacteria, the innate immune system of the host induces a strong local inflammatory response, which is characterized by an intense recruitment of polymorphonuclear leukocytes to the periodontal tissues [13]. These cells produce massive amounts of superoxide radicals $\left(\mathrm{O}_{2} \bullet-\right)$ which are subsequently released into the extracellular environment and converted into a multitude of radical and non-radical derivatives, such as hydrogen peroxide $\left(\mathrm{H}_{2} \mathrm{O}_{2}\right)$, hypochlorous acid $(\mathrm{HOCl})$, hydroxyl radical $(\mathrm{OH} \bullet)$ and singlet oxygen $\left({ }^{1} \mathrm{O}_{2}\right)$. These reactive oxygen species (ROS) are known to play a significant role in the pathogenesis of periodontitis through direct destruction of biomolecules and signalling the release of inflammatory mediators [14, 15]. Therefore, any antiperiodontopathic medicine used in prophylaxis or treatment of periodontitis must have antibacterial effects against the periodontopathic bacteria or/and cytoprotective effects against ROS to minimize periodontal tissue destruction.

The time tested Sri Lankan TBQ containing Piper betle (leaves), Syzygium aromaticum (flower buds), Myristica fragrans (seeds and mace), Elettaria cardamomum (fruits), Areca catechu (nuts), Kaempferia galanga (rhizomes) and Coriandrum sativum (seeds), which has been chewed after the three major meals (approximately $3 \mathrm{~g}$ of fresh betel leaves and $2 \mathrm{~g}$ of other ingredients in dried form) is claimed to be effective against periodontitis in the Sri Lankan folklore. However, there was no scientific evidence on these attributes of the Sri Lankan TBQ. Indeed, the scientific literature provides some evidence for the in vitro $P$. gingivalis inhibitory effects of the individual ingredients in the TBQ [16-22], but the final antibacterial effect of a herbal mixture cannot be calculated by adding their individual antibacterial effects since synergistic and antagonistic interactions among them also contribute to the final outcome [23]. The antioxidant effects analyzed in cell free systems also have been reported for the individual ingredients [24-30], but their cytoprotective effects depend on the bioavailability of them in the relevant tissues [31, 32]. Thus, this study was undertaken to investigate the potential antibacterial effects of the TBQ against the keystone periodontopathic bacterium, $P$. gingivalis and its potential antioxidant effects against oxidative stress induced damage to fibroblasts; the principal cell type in the periodontium. In addition, the safety of the TBQ extract was investigated using the cytokinesis block micronucleus (CBMN) assay on human PBLs.

\section{Methods \\ Plant materials}

Leaves of Piper betle were obtained from the betel research institute, Narammala, Sri Lanka. Seeds of Areca catechu, fruits of Elettaria cardamomum, Seeds and mace of Myristica fragrans, flower buds of Syzygium aromaticum, and rhizomes of Kaempferia galanga were obtained from local spice growers in the Central Province, Sri Lanka. Seeds of Coriandrum sativum were purchased from a local indigenous herbal product vendor. All plant ingredients were authenticated by the botanist at the national herbarium, Royal Botanical Gardens, Peradeniya, Sri Lanka. Their voucher specimens (MP2017001MP2017003 and MP2018001-MP2018004) were deposited at the same herbarium (Table 1).

\section{Preparation of the TBQ extract}

Fresh samples of the herbal ingredients were washed and air dried. Afterwards, they were ground into a fine powder and mixed in equal portions. Ten grams of this mixture were extracted in $100 \mathrm{ml}$ of ethyl acetate (EA). Extractions were done in a soxhlet apparatus for $2 \mathrm{~h}$ at $30{ }^{\circ} \mathrm{C}$ and the extracts were concentrated under reduced pressure in a rotary evaporator and lyophilized. The yield of the dried extract was $30.5 \pm 1.9 \%$. w/w $(n=3)$. The dried extracts were stored at $-20{ }^{\circ} \mathrm{C}$ and reconstituted in dimethyl sulfoxide (DMSO) and filter sterilized using $0.2 \mu \mathrm{m}$ nylon filters before analyses.

\section{Chemicals and equipment}

Ethyl acetate and $\mathrm{H}_{2} \mathrm{O}_{2}$ were purchased from BDH, UK. dimethyl sulfoxide (DMSO), 1'1' diphenyl 2 picrylhydrazyl (DPPH), ferric chloride, ferrous sulphate, methanol, 2,4,6-triphyridyl-s-triazine (TPTZ), and 2,2-azinobis-(3ethylbenzothiazolin-6-sulfonic acid (ABTS), potassium persulfate, ascorbic acid, gallic acid, trolox and 3-(4,5- 
Table 1 Common names, botanical names and the morphological parts of the constituent medicinal plants of the TBQ

\begin{tabular}{llll}
\hline Common name & Botanical name & Morphological part of the plant & Classification number \\
\hline Clove & Syzygium aromaticum (L.) Merr. \& Perry & Flower buds & MP2017001 \\
Cardamom & Elettaria cardamomum (L.) Maton & Fruits & MP2017002 \\
Coriander & Coriandrum sativum L. & Seeds & MP2017003 \\
Betel & Piper betle L. & Leaves & MP2018001 \\
Areca nut & Areca catechu L. & Seeds & MP2018002 \\
Nutmeg- seed & Myristica fragrans Houtt. & Seeds \& Seed coverings & MP2018003 \\
Java galangal & Kaempferia galanga L. & Rhizomes & MP2018004 \\
\hline
\end{tabular}

dimethylthiazole-2-yl)-2,5-diphenyl-etrazoliumbromide (MTT) were purchased from Sigma-Aldrich Inc. (USA). Dulbecco's modified eagle's medium (DMEM), Rosswell Park Memorial Institute (RPMI) 1640 medium, foetal bovine serum (FBS), penicillin/streptomycin, glutamine, phytohaemagglutinin and cytochalasin B were purchased from Gibco BRL (USA). Bleomycin (BLM) was purchased from United Biotech, India. Brain heart infusion (BHI) broth, BHI agar, blood agar and anaerobic sachets were from Oxoid (UK). Defibrinated sheep blood was from the Veterinary Research Institute, Gannoruwa, Sri Lanka. UV-1800 UV-Vis spectrophotometer, Shimadzu, Japan and Multiskan Ex plate reader from Thermoscientific, USA, were used for antioxidant and MTT assays respectively.

\section{Bacteria}

P. gingivalis (ATCC 33277 ) was obtained from the American Type Culture Collection and revived on blood agar supplemented with $5 \%$ sheep blood, hemin $(5 \mathrm{mg} /$ $\mathrm{ml})$ and vitamin $\mathrm{K} 1(0.5 \mu \mathrm{g} / \mathrm{ml})$ under anaerobic conditions for $7 \mathrm{~d}$ at $37^{\circ} \mathrm{C}$. After verifying the colony morphology and bacterial morphology after Gram staining, the bacterium was inoculated to $\mathrm{BHI}$ broth containing he$\min (5 \mathrm{mg} / \mathrm{ml})$ and vitamin $\mathrm{K} 1(0.5 \mu \mathrm{g} / \mathrm{ml})$ and incubated under anaerobic conditions for $3 \mathrm{~d}$. P. gingivalis stock cultures prepared from this broth culture were maintained in $40 \% \mathrm{v} / \mathrm{v}$ glycerol at $-80{ }^{\circ} \mathrm{C}$ throughout the study period.

\section{Antibacterial effects of the TBQ extract against $P$. gingivalis using agar well diffusion assay}

EA extract dissolved in 10\% DMSO was tested for dose dependant antimicrobial effects using agar well diffusion assay as described by Madduluri et al. [33] and Gamboa et al. [34]. The stock culture of the bacterium was grown on sheep blood agar supplemented with $5 \%$ sheep blood, hemin $(5 \mathrm{mg} / \mathrm{ml})$ and vitamin $\mathrm{K} 1(0.5 \mu \mathrm{g} / \mathrm{ml})$ for $7 \mathrm{~d}$ under anaerobic conditions. After verifying the colony morphology of cultured bacteria, 3-5 colonies were cultured in BHI broth supplemented with hemin $(5 \mathrm{mg} / \mathrm{ml})$ and vitamin $\mathrm{K} 1(0.5 \mu \mathrm{g} / \mathrm{ml})$ under anaerobic conditions for $72 \mathrm{~h}$. This culture of $P$. gingivalis was adjusted to 0.5 McFarland standard; $1.5 \times 10^{8}$ Colony Forming Units $(\mathrm{CFU} / \mathrm{ml})$ and streaked on the surface of agar using a sterile swab. Then $9 \mathrm{~mm}$ wells were made on agar plates using a stainless steel borer. Afterwards, the wells were filled with $200 \mu \mathrm{l}$ of the extract at concentrations of 7.5 , 15 and $30 \mathrm{mg} / \mathrm{ml}$. Gentamycin $(0.1 \mathrm{mg} / \mathrm{ml})$ and $0.2 \%$ chlorhexidine were used as positive controls and $10 \%$ DMSO was used as a negative control. After incubating the plates for $72 \mathrm{~h}$, bacterial colonies became visible on the surface of the agar plates except in the areas of growth inhibition around the wells. It took $5 \mathrm{~d}$ for the bacteria to develop black pigments. The zones of inhibition were measured using a micrometer gauge. Extracts which showed clear zones around the wells were considered to have an inhibitory effect on the bacterium and those which did not show clear zones without bacterial growth were considered to have no inhibitory effect on the bacterium.

\section{Antibacterial effects of the TBQ extract against $P$. gingivalis using minimum bactericidal concentration (MBC)}

The MBC was determined by standard broth micro dilution assay according to CLSI guidelines [35]. Briefly, 2fold serial dilutions of the extracts were prepared and added to BHI broth supplemented with haemin and vitamin K1. The final concentrations of the extract in the wells ranged from $62.5 \mu \mathrm{g} / \mathrm{ml}-8 \mathrm{mg} / \mathrm{ml}$. The microtitre plate wells were inoculated with an inoculum of $10^{5}$ $\mathrm{CFU}$ and incubated at $37^{\circ} \mathrm{C}$ for $72 \mathrm{~h}$ under anaerobic conditions. Afterwards, $2 \mu \mathrm{l}$ of each culture was spotted on to a fresh solid medium and incubated for $5 \mathrm{~d}$ under same conditions. The lowest concentration that yielded no bacterial growth on solid medium was taken as the MBC.

\section{Total phenolic content (TPC)}

TPC of the TBQ extract was measured as described by Singleton and Rossi [36]. First, the dried extract was dissolved in DMSO to obtain a $0.5 \mathrm{mg} / \mathrm{ml}$ solution. Then, a $200 \mu \mathrm{l}$ of sample was mixed with $1 \mathrm{ml}$ of $1: 10$ diluted 
Folin Ciocalteu reagent, and incubated at room temperature for $10 \mathrm{~min}$. Afterwards, $800 \mu \mathrm{l}$ of $7.5 \%$ (w/v) solution of $\mathrm{Na}_{2} \mathrm{CO}_{3}$ was added and incubated for further $30 \mathrm{~min}$ at room temperature. Absorbance was measured at $743 \mathrm{~nm}$. Gallic acid standards in the range of 20$100 \mu \mathrm{g} / \mathrm{ml}$ were used for preparation of the standard curve. Results are expressed as mg of gallic acid equivalents/g of dry weight (DW) of the extract.

\section{DPPH radical scavenging activity}

$\mathrm{DPPH}$ radical scavenging activity of the TBQ extract was measured as described by Williams et al. [37]. For each sample 5 different concentrations $(12.5,25,50,75$, and $100 \mu \mathrm{g} / \mathrm{ml}$ ) were tested. Briefly, $200 \mu \mathrm{l}$ of the sample $(0.5 \mathrm{mg} / \mathrm{ml})$ diluted in DMSO was added to $1.8 \mathrm{ml}$ of 1 $\mathrm{mM}$ DPPH-methanol solution. The samples were incubated for $30 \mathrm{~min}$ at room temperature and the absorbance was read at $517 \mathrm{~nm}$. DPPH-methanol solution with $200 \mu \mathrm{l}$ of DMSO was used as the blank control. Inhibition percentage for each concentration was calculated using the following equation.

Percentage inhibition $=\frac{\text { Absorbance of the blank }- \text { Absorbance of the sample }}{\text { Absorbance of the blank }} \times 100$

For each sample, percentage inhibition was plotted against the concentration and $\mathrm{IC}_{50}$, which is defined as the amount of antioxidant required to inhibit the initial DPPH concentration by $50 \%$ was calculated. A higher DPPH radical scavenging activity is reflected by a lower $\mathrm{IC}_{50}$ value.

\section{Trolox equivalent antioxidant capacity (TEAC)}

TEAC of the TBQ extract was analyzed as described by Rei et al. [38]. For this assay, ABTS radical cation $\left(\mathrm{ABTS}^{*+}\right.$ ) was produced by reacting a $7 \mathrm{mM}$ ABTS stock solution with $2.45 \mathrm{mM}$ potassium persulfate (final concentration) and incubating the mixture at room temperature in the dark for $16 \mathrm{~h}$. The $\mathrm{ABTS}^{\cdot+}$ solution was diluted with methanol to obtain an absorbance of 0.70 at $734 \mathrm{~nm}$ and the assay was carried out by mixing $10 \mu \mathrm{l}$ of the sample $(1 \mathrm{mg} / \mathrm{ml})$ with $1 \mathrm{ml}$ of reagent and incubating it for $6 \mathrm{~min}$ at $30^{\circ} \mathrm{C}$. Trolox, a water soluble vitamin $\mathrm{E}$ analogue was used as the standard and the results are expressed as mg of trolox equivalents /g of DW of the extract.

\section{Ferric reducing antioxidant power (FRAP)}

FRAP of the TBQ extract was estimated by the method of Benzie and Strain [39]. The FRAP reagent was freshly prepared by mixing $10 \mathrm{mM}$ TPTZ solution in $40 \mathrm{mM}$ $\mathrm{HCl}, 20 \mathrm{mM} \mathrm{FeCl}_{3}$, and $300 \mathrm{mM}$ acetate buffer (pH 3.6) in $1: 1: 10(\mathrm{v} / \mathrm{v} / \mathrm{v})$ proportions. Afterwards, $20 \mu \mathrm{l}$ of the sample $(0.2 \mathrm{mg} / \mathrm{ml})$ was mixed with $1 \mathrm{ml}$ of the reagent, incubated for $4 \mathrm{~min}$ at room temperature and observed the absorbance at $593 \mathrm{~nm}$. $\mathrm{FeSO}_{4}$ solutions in the concentration range of $200-1000 \mu \mathrm{M}$ were used to plot the standard curve. The FRAP was expressed as millimoles of ferrous equivalents/g of DW of the extract.

\section{Assessment of the cytotoxicity of the TBQ extract}

To identify a suitable concentration of this extract to be applied in cytoprotective assays, it was initially screened for cytotoxic effects using MTT assay as described by Illeperuma et al. [40]. For this purpose, human gingival fibroblasts, HGF-1 (ATCC-CRL 2014) obtained from the American Type Culture Collection (ATCC, Manassas, VA, USA), were cultured in DMEM-F12 medium supplemented with, $10 \%$ heat-inactivated FBS, $2 \mathrm{mML}$ glutamine, penicillin $(100 \mathrm{IU} / \mathrm{ml})$ and streptomycin $(100 \mu \mathrm{g} / \mathrm{ml})$ at a density of $2 \times 10^{4}$ cells/well in 96 well cell culture plates (Corning) and incubated in a humidified, $5 \% \mathrm{CO}_{2}$ incubator at $37^{\circ} \mathrm{C}$. Afterwards, cells were treated with the TBQ extract serially diluted in DMEM containing $1 \%$ DMSO as the vehicle for 1,3 and 5 days. BLM at a concentration of $100 \mu \mathrm{g} / \mathrm{ml}$ served as the positive control and DMEM containing 1\% DMSO served as the negative control. After treatment, the cells were rinsed three times with phosphate buffered saline (PBS) $\mathrm{pH}$ 7.4, and the MTT assay was performed as described in Methods in Molecular Biology [41]. The absorbance was measured at $570 \mathrm{~nm}$ and $620 \mathrm{~nm}$ and the data were normalized to the negative control.

\section{Assessment of the cytoprotective effect of the TBQ extract}

Cytoprotective effect of the tested extract against $\mathrm{H}_{2} \mathrm{O}_{2}$ induced cytotoxicity on HGF-1 cells was tested according to the method used by Sazwi et al. [42]. Based on the cytotoxicity assay results, a dose of $100 \mu \mathrm{g} / \mathrm{ml}$ of the TBQ extract was selected as a suitable dose for the assessment of cytoprotectivity. For this assay also, the cells were seeded and incubated as described above. When the cells became $70 \%$ confluent, the medium was aspirated and replaced with new medium containing $100 \mu \mathrm{g} /$ $\mathrm{ml}$ of the TBQ extract and incubated for another $24 \mathrm{~h}$. Subsequently, the cells were rinsed three times with PBS and treated with different concentrations of $\mathrm{H}_{2} \mathrm{O}_{2}(0-2$ $\mathrm{mM}$ ) for $6 \mathrm{~h}$ under standard conditions. The control samples were treated with medium only. Finally, the cells were rinsed with PBS three times and the MTT assay was performed as described elsewhere [41]. The data were normalized to negative control.

\section{Assessment of the safety of the TBQ extract}

Safety of the TBQ extract for human use was analyzed using Cytokinesis Block Micronucleus (CBMN) assay, 
which is recommended by the Food and Drug Administration, USA for testing pharmaceuticals intended for human use [43, 44]. Briefly, peripheral venous blood was collected into heparinized tubes from 4 healthy voluntary donors (two males and two females; $30-50 \mathrm{yr}$ who were non-smoking, non-betel quid chewing and with no recent history of radiation exposure) after obtaining informed written consent. For each individual, five peripheral blood lymphocyte (PBL) cultures were set up, each containing $500 \mu \mathrm{l}$ of whole blood and $4.5 \mathrm{ml}$ of RPMI 1640 culture medium supplemented with 10\% FBS, $200 \mathrm{mML}$ glutamine, penicillin (100 units $/ \mathrm{ml}$ ) and streptomycin $(100 \mathrm{mg} / \mu \mathrm{l})$. First culture served as the negative control and was added with 1\% DMSO. Second culture served as the positive control and added with $40 \mu \mathrm{g} /$ $\mathrm{ml}$ BLM. Third and fourth cultures which served as TBQ genotoxicity tests were added with $250 \mu \mathrm{g} / \mathrm{ml}$ and $2.5 \mathrm{mg} / \mathrm{ml}$ of TBQ extract respectively. Fifth culture which served as TBQ antigenotoxicity test was added with $40 \mu \mathrm{g} / \mathrm{ml}$ BLM after preincubating the cells in $2.5 \mu \mathrm{g} / \mathrm{ml}$ TBQ extract for $3 \mathrm{~h}$. All cultures were incubated for $3 \mathrm{~h}$ at $37^{\circ} \mathrm{C}$ in a humidified $\mathrm{CO}_{2}$ incubator. Subsequently, cells in each culture were washed with PBS, re-suspended in $4.5 \mathrm{ml}$ of complete medium, added with $5 \mu \mathrm{g} / \mathrm{ml}$ of phytohaemagglutinin, and incubated for another $44 \mathrm{~h}$. Then, cytokinesis was arrested by adding $3 \mu \mathrm{g} / \mathrm{ml}$ of cytochalasin-B to the culture. After another $28 \mathrm{~h}$, the cells were harvested with a brief hypotonic treatment and fixed with Carney's fixative (methanol:acetic acid - 3:1). Thereafter, cell suspensions were dropped on to clean glass slides, air dried and stained with Giemsa stain. All the slides were coded and scored blindly. Thousand binucleated lymphocytes with a preserved cytoplasm were counted and the frequency of micronuclei $(\mathrm{MN})$ was expressed as a percentage.

\section{Statistical analysis}

For antibacterial assays, antioxidant assays, cytotoxicity assays and cytoprotective assays, three independent extracts $(n=3)$ were analyzed on three different days and the results are expressed as mean \pm standard deviation (SD). For CBMN assay, the micronuclei were counted in 1000 binucleated cells from 4 independent cultures $(n=4)$ and the MN frequency is expressed as a percentage. The sample means were compared by ANOVA followed by post hoc Tukey's test. In addition, for the cytoprotective assay, Student $t$ test was also used to compare the means of TBQ treated and untreated groups. $P<0.05$ was considered significant. Data were analyzed using Graph Pad Prism software (version 6, USA).

\section{Results}

Antibacterial effect of the TBQ extract against $P$. gingivalis Initial screening of the TBQ extract using agar well diffusion assay revealed that it has inhibitory effects against $P$. gingivalis. As shown in Fig. 1, the zones of inhibition at concentrations of $7.5,15$ and $30 \mathrm{mg} / \mathrm{ml}$ of the extract against this bacterium were, $(14.33 \pm 1.15) \mathrm{mm},(16.33 \pm$ $2.08) \mathrm{mm}$ and $(17.50 \pm 1.80) \mathrm{mm}$ respectively while the negative control (10\% DMSO) had no detectable inhibition. The zones of inhibition for the positive controls (gentamycin and chlorhexidine) were $24.0 \pm 1.2 \mathrm{~mm}$ and $18.0 \pm 0 \mathrm{~mm}$ respectively. When the same extract was tested using broth micro dilution method, it showed a MBC of $125 \pm 0 \mu \mathrm{g} / \mathrm{ml}$.

\section{TPC and antioxidant potential of the extract}

Next we analyzed this TBQ extract for its TPC since plant polyphenols are known to be the major phytochemical responsible for their antioxidant effects. As shown in Table 2, TBQ extract has a TPC of $114.0 \pm 1.3 \mathrm{mg}$ of gallic acid equivalents/g of DW. The $\mathrm{IC}_{50}$ value for its $\mathrm{DPPH}$ radical scavenging activity was $20.6 \pm 1.8 \mu \mathrm{g} / \mathrm{ml}$ while the ABTS radical scavenging activity was $624.8 \pm 8.5 \mathrm{mg}$ of trolox equivalents/g of DW. Its FRAP was found to be $3688.9 \pm 223.8 \mathrm{mmol} / \mathrm{g}$ of DW.

The results are expressed as mean $\pm \mathrm{SD}$ of 3 independent experiments. " indicates standard antioxidants.

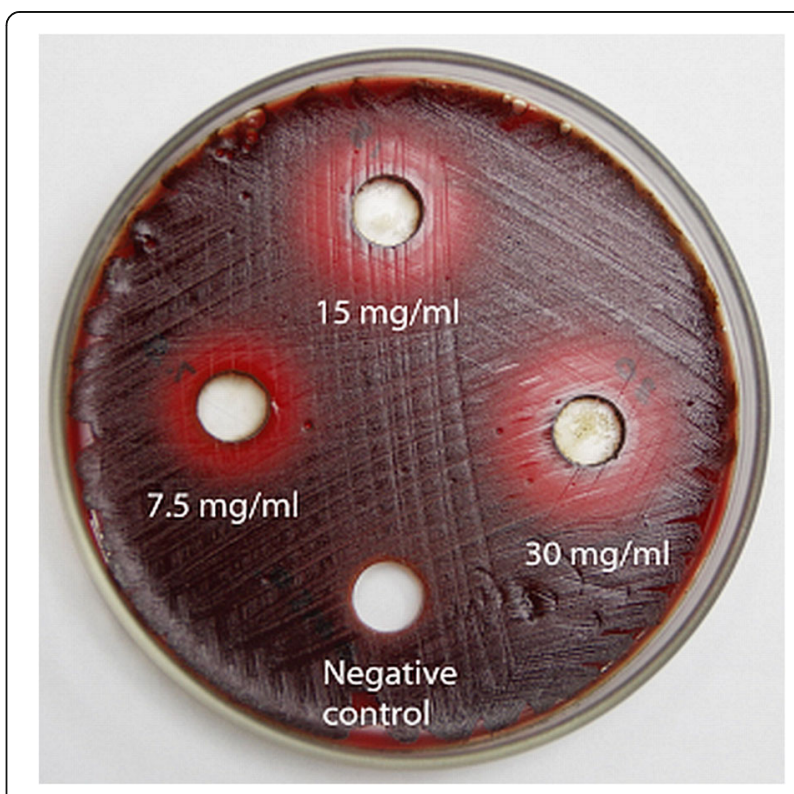

Fig. 1 A photograph of a bacterial culture plate showing the dose dependent growth inhibitory effects of the TBQ extract on P.gingivalis. The clear zones around the wells indicate the zone of inhibition 
Table 2 Antioxidant potential and the TPC of the EA extract of the Sri Lankan TBQ

\begin{tabular}{lllll}
\hline $\begin{array}{l}\text { Extract/ } \\
\text { Positive } \\
\text { control }\end{array}$ & $\begin{array}{l}\text { DPPH radical } \\
\text { scavenging activity } \\
\left(\mathrm{I} \mathrm{C}_{50}: \mu \mathrm{g} / \mathrm{ml}\right)\end{array}$ & $\begin{array}{l}\text { ABTS radical scavenging activity } \\
\text { (mg of trolox equivalents /g of DW) }\end{array}$ & $\begin{array}{l}\text { Ferric reducing antioxidant power } \\
\text { (mmol of ferrous equivalents /g of } \\
\text { DW) }\end{array}$ & $\begin{array}{l}\text { Phenolic content (mg of gallic } \\
\text { acid equivalents /g of DW) }\end{array}$ \\
\hline $\begin{array}{l}\text { TBQ extract } \\
20.6 \pm 1.8\end{array}$ & $624.8 \pm 8.5$ & $3688.9 \pm 223.8$ & $114.0 \pm 1.3$ \\
$\begin{array}{l}\text { Ascorbic } \\
\text { acid* }\end{array}$ & $4.2 \pm 0.1$ & $1263.8 \pm 39.0$ & $8068.4 \pm 62.3$ & - \\
Trolox* & $6.3 \pm 0.1$ & - & $5176.8 \pm 33.0$ & - \\
\hline
\end{tabular}

\section{Cytotoxicity of the extract}

Before applying the TBQ extract to cell cultures for analyzing its cytoprotective effects on gingival fibroblasts, we analyzed its cytotoxicity using the MTT assay. As shown in Fig. 2, even a dose of $250 \mu \mathrm{g} / \mathrm{ml}$ of the TBQ extract did not display a significant cytotoxic effect on cultured human gingival fibroblasts after 24 and $48 \mathrm{~h}$. Even after $72 \mathrm{~h}$, the TBQ extract did not show significant cytotoxic effect at doses $<125 \mu \mathrm{g} / \mathrm{ml}$. However, cytotoxic effects were detected after $72 \mathrm{~h}$, when the cells were exposed to $>125 \mu \mathrm{g} / \mathrm{ml}$ of the extract. At the highest dose of the TBQ extract tested in this study $(500 \mu \mathrm{g} / \mathrm{ml})$, cytotoxic effects could be detected even after $24 \mathrm{~h}$. Therefore, it was decided to expose the HGF-1 cells to this extract at a dose of $100 \mu \mathrm{g} / \mathrm{ml}$ for $24 \mathrm{~h}$ when analyzing its cytoprotective effect against oxidative stress.

\section{Cytoprotective effect of the extract}

Next, we attempted to see whether the potent antioxidant activities detected in the TBQ extract were capable of protecting human gingival fibroblasts from oxidative stress induced cytotoxicity. This was tested by challenging the gingival fibroblasts with $\mathrm{H}_{2} \mathrm{O}_{2}$ after preincubating the cells with the TBQ extract at a dose of $100 \mu \mathrm{g} /$ $\mathrm{ml}$ for $24 \mathrm{~h}$. As shown in Fig. 3, the cells treated with $\mathrm{H}_{2} \mathrm{O}_{2}$ for $6 \mathrm{~h}$ exhibited a significant reduction in cell viability when compared with the control cells. However, for each tested dose of $\mathrm{H}_{2} \mathrm{O}_{2}$, the reduction in viability of the cells pretreated with the TBQ extract was significantly lower than that of the cells which were not pretreated with the TBQ extract.

\section{Safety of the TBQ extract}

Finally, we explored the safety of the TBQ extract using the CBMN assay. As shown in Fig. 4, the mean MN frequency in the negative control group (0.1\% DMSO) was $1.28 \pm 0.61 \%$. The $\mathrm{MN}$ frequencies of the TBQ treated group at concentrations of $250 \mu \mathrm{g} / \mathrm{ml}$ and $2.5 \mathrm{mg} / \mathrm{ml}$ were $2.08 \pm 0.30 \%$ and $2.08 \pm 1.37 \%$ respectively. These $\mathrm{MN}$ frequencies were not significantly different from

\section{HGF-1}

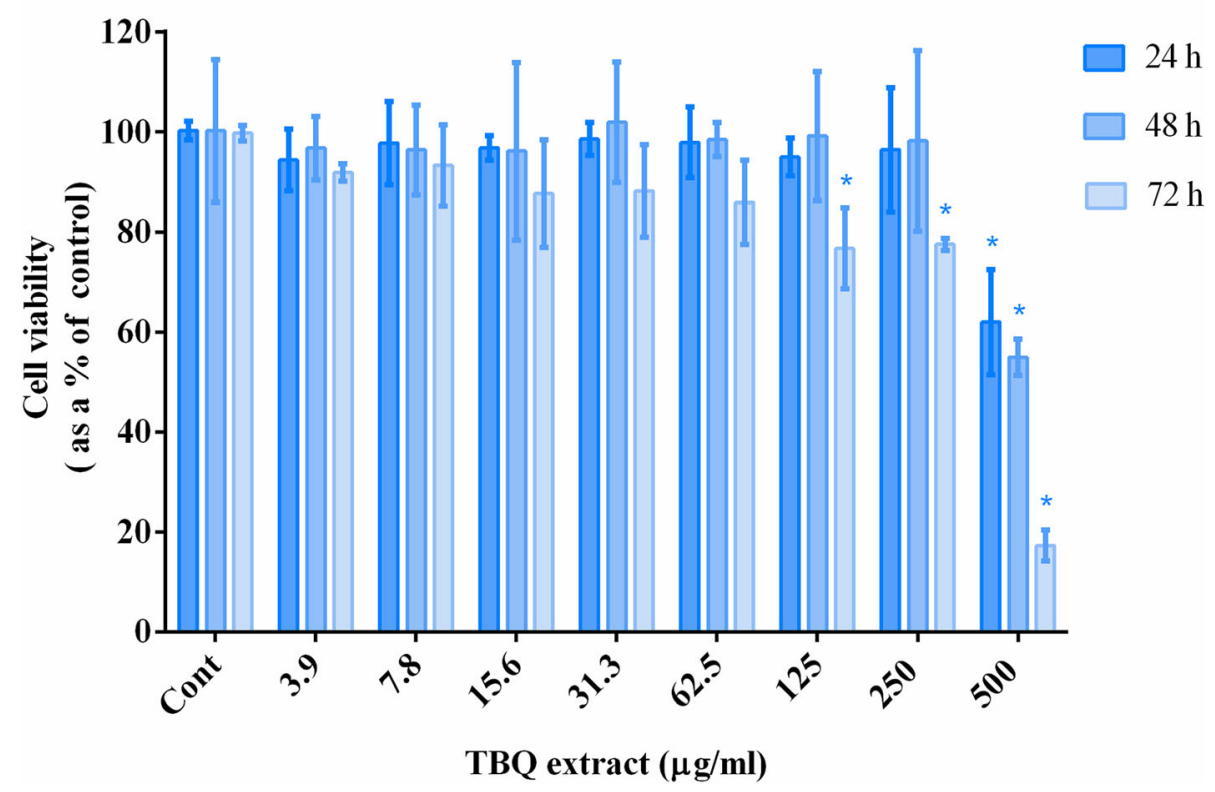

Fig. 2 Time and dose dependant effects of the TBQ extract on the viability of HGF-1 cells. The bars represent the mean of 3 independent experiments $(n=3)$ and the error bars represent their standard deviation. The mean of the data denoted by * is significantly different from that of the corresponding negative control. The level of significance was $P<0.05$ 


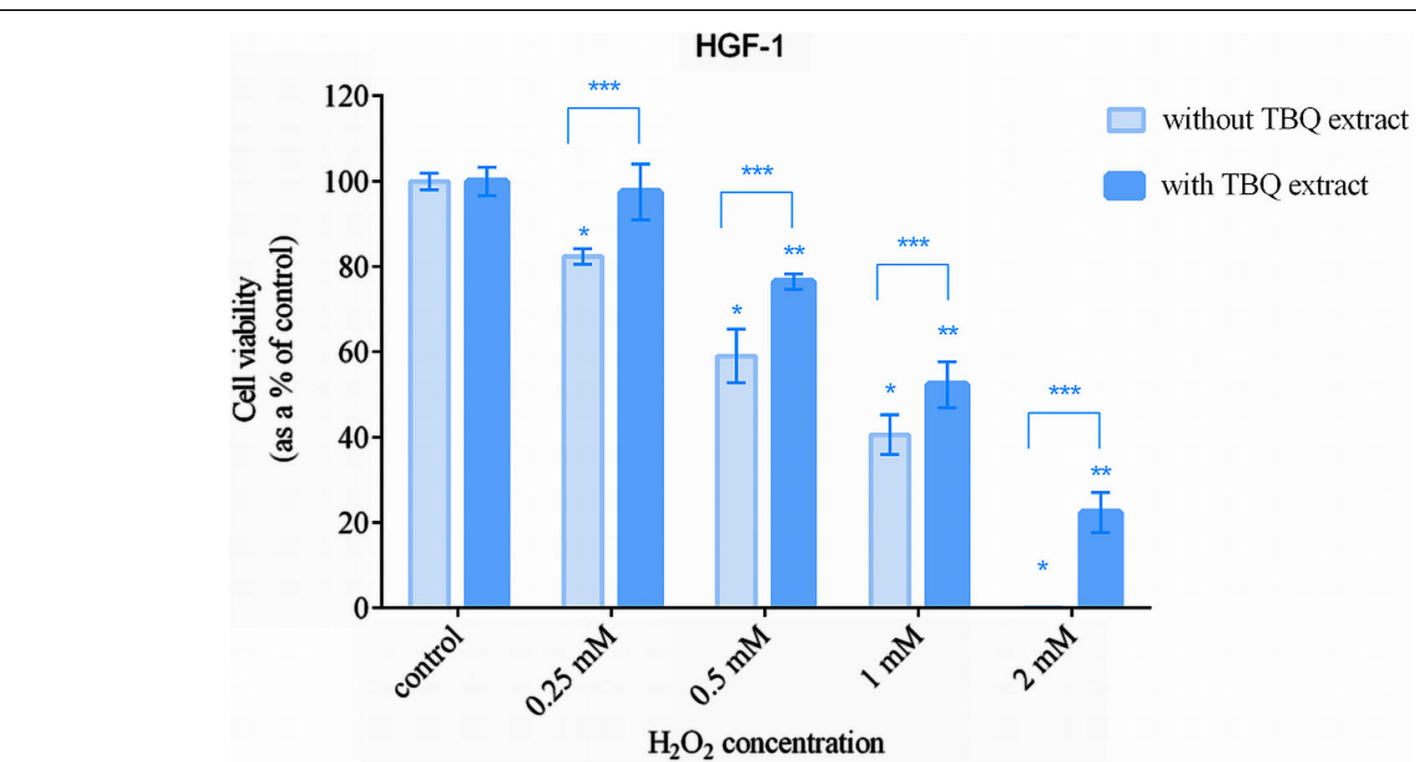

Fig. 3 Dose dependent effects of $\mathrm{H}_{2} \mathrm{O}_{2}$ on the viability of HGF-1 cells with and without pretreating with the TBQ extract at a dose of $100 \mu \mathrm{g} / \mathrm{ml}$ for $24 \mathrm{~h}$. The bars represent the mean of 3 independent experiments $(n=3)$ and the error bars represent their standard deviation. The data denoted by ${ }^{*}$ and ${ }^{* *}$ are significantly different from the corresponding negative control. The data denoted by ${ }^{* *}$ is significantly different from that of the test without TBQ extract. The level of significance was $P<0.05$

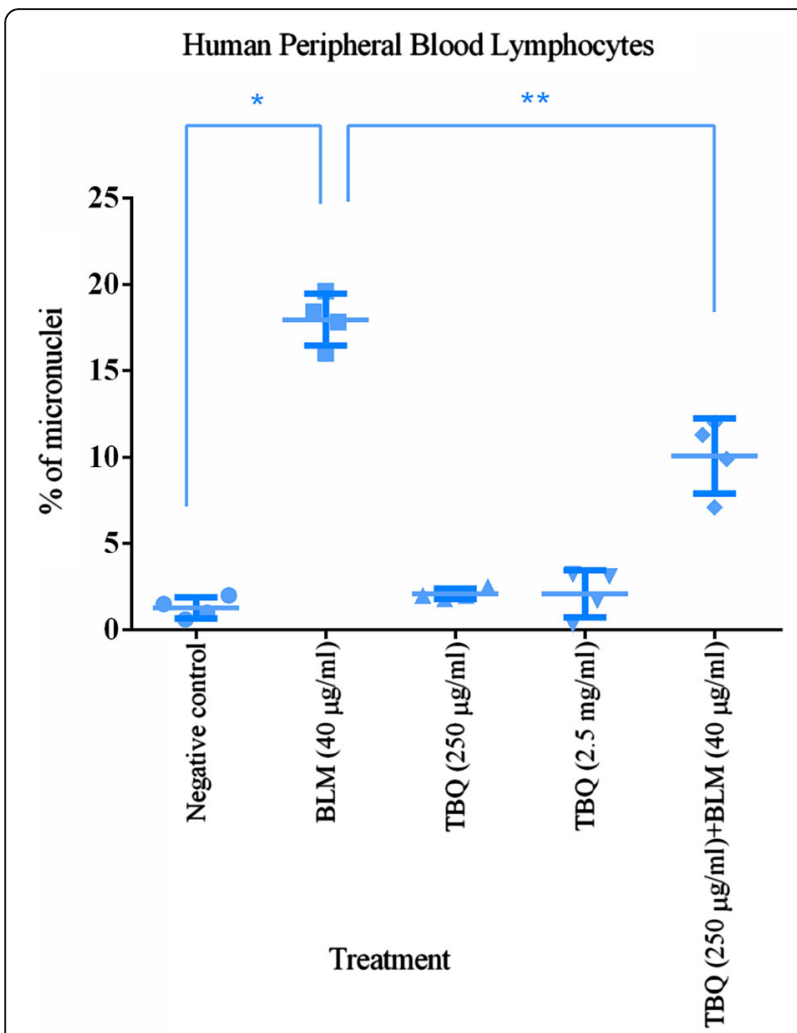

Fig. 4 CBMN assay data, expressed as the \% of micronuclei in 1000 binucleated lymphocytes for 4 individuals in each treatment group with mean and SD. The data denoted by * and ** are significantly different from the BLM treated group. The level of significance was $P<0.05$ that of the negative control group. In contrast, the MN frequency of the positive control (BLM treated) group was significantly higher than that of the negative control group $(18.85 \pm 0.90 \%)$. Interestingly, BLM induced MN formation was significantly reduced $(10.08 \pm 2.17 \%)$ when BLM was added after pre-treating the cells with the TBQ extract for $3 \mathrm{~h}$.

\section{Discussion}

Periodontitis is a multifactorial disease. The primary cause of periodontitis is infection of periodontal tissues with periodontopathic bacteria. Among them, $P$. gingivalis has been identified as the keystone bacterium. In the present study, we first show that the EA extract of the Sri Lankan TBQ is a rich source of natural antibacterial compounds against $P$. gingivalis with a $\mathrm{MBC}$ value of $125 \mu \mathrm{g} / \mathrm{ml}$. It provides clear evidence for the $P$. gingivalis inhibitory effects of the Sri Lankan TBQ, which must be partly responsible for its claimed antiperiodontopathic effects.

When we compared the $P$. gingivalis inhibitory effects of the TBQ extract tested in this study with those reported for its individual ingredients, it was higher in the TBQ extract than that of most of its individual ingredient extracts. For example, EA extract of $M$. fragrans seeds and methanol extract of $K$. galanga were reported to have MBCs of $250,320 \mu \mathrm{g} / \mathrm{ml}$ respectively [20, 21] while methanol extract of $S$. aromaticum was reported

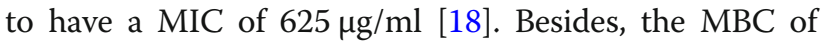
$M$. fragrans mace has been reported to be $>640 \mu \mathrm{g} / \mathrm{ml}$ 
[20]. Even though MIC and MBC values were not reported for crude extracts of $P$. betle and A. catechu, certain phytochemicals isolated from these ingredients were reported to have $P$. gingivalis inhibitory effects. For example, one of the major polyphenols in $P$. betle (hydroxychavicol) was reported to have a MBC between 62.5$500 \mu \mathrm{g} / \mathrm{ml} \mathrm{[16]} \mathrm{and} \mathrm{tannic} \mathrm{acid,} \mathrm{one} \mathrm{of} \mathrm{the} \mathrm{major} \mathrm{poly-}$ phenols in A. catechu, was reported to have a ZOI of 2 $\mathrm{mm}$ against $P$. gingivalis using disc diffusion assay [17]. On the other hand, essential oils from coriander leaves were reported to have a MBC of $125 \mu \mathrm{g} / \mathrm{ml}$ [22].

Moreover, the $P$. gingivalis inhibitory effect of the tested Sri Lankan TBQ extract was higher than that of many other herbal extracts reported to have antiperiodontopathic effects. Even the MICs of the water extract of Polygonum tinctorium Lour (MIC: $1.74 \mathrm{mg} / \mathrm{ml}$ ), methanol extract of Terminalia laxiflora (MIC: $0.25 \mathrm{mg} / \mathrm{ml}$ ), methanol extracts of Ambrosia maritima (MIC:0.5 mg/ $\mathrm{ml}$ ), seeds of Argemone mexicana (MIC: $0.5 \mathrm{mg} / \mathrm{ml}$ ), wood and bark of Terminalia brownii (MIC: $0.5 \mathrm{mg} / \mathrm{ml}$ ), bark of Combretum hartmannianum (MIC: $0.5 \mathrm{mg} / \mathrm{ml}$ ), bark of Acacia tortilis (MIC:0.5 mg/ml) and the ethanol extract of Piper marginatum Jacq (MIC: $1 \mathrm{mg} / \mathrm{ml}$ ), ethanol extract of Ilex guayusa Loes (MIC: $1 \mathrm{mg} / \mathrm{ml}$ ) methanol extract of Phytolacca americana (MIC: $600 \mu \mathrm{g} / \mathrm{ml}$ ), water extract of Camellia sinensis/green tea (MIC: 12.5 $\mathrm{mg} / \mathrm{ml}$ ), ethanolic extract of Allium sativum/garlic (MIC: $62.5 \mathrm{mg} / \mathrm{ml}$ ), ethanolic extract of Mammea americana (MIC: $500 \mu \mathrm{g} / \mathrm{ml}$ ), and the water extract of Castanopsis lamontii (MIC: $625 \mu \mathrm{g} / \mathrm{ml}$ ) were higher than the MBC of the TBQ extract against $P$. gingivalis [34, 4551]. According to Kohlie et al., ethanol extract of the husk of Coccus nucifera also has a lower $P$. gingivalis inhibitory effect (MBC:1562.5 $\mu \mathrm{g} / \mathrm{ml}$ ) compared to that of the tested TBQ extract [52].

Another factor which has been previously demonstrated to have a significant contribution to the pathogenesis of periodontitis is oxidative stress. It has been found that exogenous antioxidants can be used to counteract the tissue oxidative stress by boosting the endogenous antioxidant defence mechanisms. Specially, plant polyphenols have been known to play a key role in this process [53]. According to our results, the Sri Lankan TBQ has a TPC of $114.0 \pm 1.3 \mathrm{mg}$ of GAE /g of DW showing it to be a rich source of polyphenols.

The plant polyphenols are known to neutralize free radicals through numerous mechanisms [54]. One of them is donation of hydrogen ions to neutralize their unpaired electrons/anionic radicals. When the hydrogen ion donating potential of the TBQ extract was assessed using the DPPH radical scavenging assay, it was found to have an $\mathrm{IC}_{50}$ value of $20.6 \pm 1.8 \mu \mathrm{g} / \mathrm{ml}$, indicating its strong hydrogen ion donating ability. When this $\mathrm{IC}_{50}$ value was compared with that of purified form of ascorbic acid, the antioxidant potential of the TBQ extract was found to be approximately $20 \%$ that of ascorbic acid $\left(\mathrm{IC}_{50}\right.$ for ascorbic acid: $4.2 \pm 0.1 \mu \mathrm{g} / \mathrm{ml}$ ). Another mechanism of plant polyphenols in reducing oxidative stress is through donation of electrons. When the electron donating ability of the TBQ extract was measured using $\mathrm{ABTS}^{+}$radical scavenging assay with trolox as a standard, it showed a TEAC of $624.8 \pm 8.5 \mathrm{mg} / \mathrm{g}$ of DW, indicating that the free radical scavenging activity of this extract is comparable to approximately $50 \%$ that of ascorbic acid $(1263.8 \pm 39.0 \mathrm{mg} / \mathrm{g})$. In addition, this extract showed a considerable FRAP also $(3688.9 \pm 223.8 \mathrm{mmol} /$ $\mathrm{g}$ of DW), indicating its ability to serve as a potent antioxidant through donation of electrons. Its FRAP was $40 \%$ that of ascorbic acid $(8068.4 \pm 62.3 \mathrm{mmol} / \mathrm{g}$ of DW). Collectively, these findings provide scientific evidence to prove that this Sri Lankan TBQ extract is a rich source of natural antioxidants.

However, previous studies have shown that cytoprotective effects of plant derived antioxidants depend not only on their potency but also on their bioavailability in the cells. Therefore, if the antioxidant molecules in the TBQ have a cytoprotective effect, they must be readily available to the most abundant population of cells in the periodontium; the fibroblasts. Providing evidence for the bioavailability of these antioxidants to these cells, $\mathrm{H}_{2} \mathrm{O}_{2}$ induced cytotoxicity in cultured human gingival fibroblasts were attenuated when these cells were preincubated with the TBQ extract. Previous studies have shown that plant derived antioxidants can reduce the oxidative stress in human cells through scavenging of free radicals or induction of antioxidant enzymes [55, 56]. Thus, the protective effect of the TBQ extract against oxidative stress observed in the current study may be attributed to the ability of natural antioxidants in this extract to directly neutralize $\mathrm{H}_{2} \mathrm{O}_{2}$ molecules entering the cells or indirectly neutralize them through induction of intracellular antioxidant enzymes such as catalases and peroxidases.

The antioxidant properties we have reported for the TBQ extract in this study are comparable with results of similar studies on its individual ingredients reported in the literature. When the DPPH assay results were taken into consideration, methanol extract of $P$. betle from Sri Lanka was reported to have a $\mathrm{IC}_{50}$ of $12.66 \pm 0.07 \mu \mathrm{g} / \mathrm{ml}$ and a water extract of a Malaysian variety of $A$. catechu was reported to have a $\mathrm{IC}_{50}$ of $7.5 \pm 0.5 \mu \mathrm{g} / \mathrm{ml}[24,25]$. According to these values, the DPPH radical scavenging activities of $P$. betle and A. catechu are higher than that of the TBQ extract tested in this study. In contrast, the $\mathrm{IC}_{50}$ for the ethanol extract of S. aromaticum (42 \pm $7.4 \mu \mathrm{g} / \mathrm{ml}$ ), methanol extracts of Tunisian, Syrian and Egyptian varieties of C. sativum $(27.00 \pm 6.57 \mu \mathrm{g} / \mathrm{ml}$, $36.00 \pm 3.22 \mu \mathrm{g} / \mathrm{ml}$ and $32.00 \pm 2.87 \mu \mathrm{g} / \mathrm{ml}$ ), ethanol 
extract of E. cardamomum $(217.43 \mu \mathrm{g} / \mathrm{ml})$, mace and seed of $M$. fragrans $(49.78 \pm 2.76 \mu \mathrm{g} / \mathrm{ml}$ and $115.13 \pm$ $0.53 \mu \mathrm{g} / \mathrm{ml}$ ) were higher than that of the TBQ extract, providing evidence for their lower DPPH radical scavenging activities [29, 57-59]. K. galanga also is reported to be a rich source of antioxidants, but its DPPH radical scavenging activity cannot be compared with the results of this study since it was expressed as ascorbic acid equivalents (17 $\pm 1 \mathrm{mg} \mathrm{AA} / 100 \mathrm{~g}$ ) [60].

Finally, the safety of this TBQ extract was analyzed using the CBMN assay on cultured human PBLs, since it is a pre requisite to analyze the safety of any herbal medicine intended for human use. According to our results, this TBQ extract was not genotoxic at the highest tested dose $(2.5 \mathrm{mg} / \mathrm{ml})$. Moreover, pretreatment of the PBLs with the TBQ extract could protect these cells from BLM induced genotoxicity. This finding provides scientific evidence for the antigenotoxic potential of the TBQ extract. It is a well established fact that BLM induced genotoxicity is free radical mediated [61]. Thus, neutralization of BLM induced free radicals by the antioxidants in the TBQ extract is one of the possible mechanisms for the observed antigenotoxic effects in this study. The other possible mechanism may be induction of DNA repair enzymes contributing to repair of the DNA double strand breaks before micronuclei formation. The antigenotoxic effects shown for the TBQ extract in this study are comparable to the results of previous studies which have shown the ability of phytochemicals to neutralize the genotoxic effects of BLM $[62,63]$.

Our study provides first scientific evidence for the ability of the Sri Lankan TBQ extract to act on two etiological factors contributing to the pathogenesis of periodontitis. It clearly indicates the potential of this extract to be used in multitargeted therapy in prevention and treatment of periodontitis. Cytoprotective and antigenotoxic effects detected in this study are added advantages of this herbal mixture. It is also noteworthy that the extremely low cytotoxic and gentotoxic effects as well as the cytoprotective and antigenotoxic effects we have reported for the TBQ in this study are in contrast to the cytotoxic and genotoxic effects reported for the contemporary betel quid (CBQ) used in Sri Lanka and the other south Asian countries [64, 65].

Eventhough there are geographical variations, the major ingredients in the CBQ are betel, arecanut (> 50\% of the dry weight) and slaked lime with or without tobacco $[66,67]$. Both arecanut and tobacco in this mixture have carcinogenic potential [68]. Slaked lime in this mixture can enhance the carcinogenic potential of CBQ by creating an alkaline environment in the oral cavity and thereby enhancing the release of carcinogenic alkaloids from arecanut and generation of free radicals from those alkaloids. In addition, slaked lime can cause ulceration of the oral cavity and expose the basal layer of the oral mucosa for mutagenic compounds [69, 70]. In contrast, the TBQ tested in this study does not contain tobacco or slaked lime. However, it contains a relatively low content of arecanut (12.5\% of the mixture) when compared to the CBQ. Both epidemiological and animal studies have shown an association between arecanut and development of oral potentially malignant disorders (OPMDs) and the risk of oral cancer [68, 71, 72]. However, it has been demonstrated that such association depends on the frequency and the dose of arecanut consumption $[71,73]$. Despite this claimed potential carcinogenic effect, small doses of arecanut have been used alone or in combination with other medicinal herbs in treating diverse disease conditions in Asian traditional medicine systems [74-76]. A number of recent laboratory and clinical studies have also provided strong evidence for the therapeutic effect of low concentrations of arecoline, which is known to be the carcinogenic alkaloid in arecanut. According to Cheng et al. a low concentration of arecoline $(<100 \mu \mathrm{g} / \mathrm{ml})$ can induce death of human hepatoma cells in a targeted manner with minimal effects on normal hepatocytes [77]. The anticancer effect mediated by low doses of arecoline has been further supported by both in-vitro and in-vivo studies using cultured human cancer cell lines and in nude mice bearing tumour xenografts [78]. Moreover, in clinical studies, multiple doses of arecoline have been reported to improve the cognitive function of Alzheimer patients [79]. In a schizophrenic mouse model, arecoline was found to alleviate the memory impairment and demyelination of neurons [80]. The multiple target approach in herbal medicine primarily focusses on maximizing the therapeutic outcome mediated by multiple compounds on vast array of targets, perhaps promoting the synergism and neutralising toxic effects of each individual compound. One of the important findings related to alleviation of arecanut toxicity is co-administration antioxidants. Investigations by Illeperuma et al. have shown that antioxidant rich herbal extracts can prevent arecanut induced ROS generation and genotoxicity in immortalized human oral keratinocytes and DNA double strand breaks in a mouse model [81]. Investigations by Zhou et al. have shown that vitamins $\mathrm{C}$ and $\mathrm{E}$ can alleviate hepatoxic effects of arecanut in mice [82]. These findings support the use of arecanut in combination with other antioxidant rich herbal ingredients in traditional medicine systems, thus alleviating any possible detrimental effects [74]. In the present study, the content of arecanut accounts only for $1 / 8$ th of the TBQ mixture, while the remaining $7 / 8$ th portion is shared by seven herbal ingredients which are rich sources of natural antioxidants [24, 26-30]. Moreover, these herbal ingredients 
are reported to possess anticancer effects as well [8388]. Thus, the presence of proportionately low content of arecanut along with seven other herbal ingredients rich in antioxidants and anticancer compounds and the absence of tobacco and slaked lime in the tested TBQ justifies the observed low cytotoxic and genotoxic effects. It shows the potential of this herbal mixture to be used as a substitute for the currently used CBQ also. However, further detailed studies are suggestive to quantify the arecoline content of this TBQ extract and optimize its ingredients to obtain the maximum therapeutic effect while minimizing the toxic effects. Some of the limitations of our study are the lack of data on the antibacterial effects of TBQ extract against other periodontopathic bacteria and the clinical isolates of $P$. gingivalis. Our future studies are directed towards overcoming these limitations. Since the current trend in addressing chronic inflammatory diseases such as periodontitis is multi-targeted therapy, further in vitro and in vivo tests are warranted to understand other targets of the TBQ in the pathogenesis of periodontitis and also to develop oral health care products using this herbal mixture to control periodontitis.

\section{Conclusion}

Overall outcome of this study supports the use of the EA extract of the Sri Lankan TBQ as a combined therapy for prevention and treatment of periodontitis due to its antibacterial, antioxidant, cytoprotective and nongenotoxic effects. Thus this formulation could be developed as a promising natural mouth rinse or a periodontal gel with multiple actions for the management of gingival diseases.

\section{Abbreviations}

ABTS: 2,2-azinobis-3-ethylbenzothiazolin-6-sulfonic acid; BHI: Brain Heart Infusion; BLM: Bleomycin; CBMN: Cytokinesis block micronucleus assay; CBQ: Contemporary Betel Quid; CFU: Colony Forming Units; CLSI: Clinical and Laboratory Standard Institute; DMSO: Dimethyl sulfoxide; DMEM: Dulbecco's Modified Eagle's Medium; DPPH: 1'1’ diphenyl 2 picryl hydrazyl; DW: Dry weight; EA: Ethyl acetate; FRAP: Ferric reducing antioxidant power; GAE: Gallic acid equivalents; HGF-1: Human Gingival Fibroblasts-1; MBC: Minimum Bactericidal concentration; MN: Micronuclei; MTT: 3-(4,5dimethylthiazole-2-yl)-2,5-diphenyl-etrazoliumbromide; OPMDs: Oral Potentially Malignant Disorders; PBLs: Peripheral Blood Lymphocytes; PBS: Phosphate Buffered Saline; RPMI: Rosswell Park Memorial Institute; TBQ: Traditional Betel Quid; TEAC: Trolox equivalent antioxidant capacity: TPC: Total phenolic content; TPTZ: 2,4,6-triphyridyl-s-triazine

\section{Acknowledgements \\ The authors wish to acknowledge Prof. P. S. Rajapakse, Department of Oral Medicine and Periodontology, Faculty of Dental Sciences, University of Peradeniya, for provision of standard $P$. gingivalis cultures, Betel Research Institute, Narammala, Sri Lanka for providing betel for this study, and M. Dabarera, K. Karunathilake, M. G. B. Gangadhara, R. M. N. T. K. Rajanayake, M. R. D. M. Senanayake, S. H. K. Weerasekera and V. Viduranga for their technical support.}

\section{Authors' contributions}

MPP designed the study. NSP, TLN and AN did the extractions. MPP, TLN and NSP did the antioxidant assays in the cell free systems. MPP and JR did the cytotoxicity assays and the cell based antioxidant assays. MPP and SJ did the antibacterial assays. BPG, NSP and SW analyzed the genotoxicity. MPP analyzed the data and wrote the manuscript. BPG, TLN and KK critically reviewed the manuscript. All authors read and approved the final manuscript.

\section{Funding}

This research was financially supported by Peradeniya University Research Grant [URG AF/2013/17D]. The funder had no role in study design, conduct of experiments, data analysis, decision to publish or preparation of the manuscript.

\section{Availability of data and materials \\ The datasets analysed during the current study are available from the corresponding author on reasonable request.}

\section{Ethics approval and consent to participate}

Ethical clearance for this study was obtained from the Ethics Review Committee of the Faculty of Dental Sciences, University of Peradeniya, Peradeniya, Sri Lanka (Ethical Clearance Certificate No FDS-FRC/2014/16). All participants were recruited on voluntary basis after obtaining their informed written consent.

\section{Consent for publication}

This is not applicable as none of the participants are identified in the manuscript.

\section{Competing interests}

The authors declare that they have no competing interests.

\section{Author details}

${ }^{1}$ Department of Basic Sciences, Faculty of Dental Sciences, University of Peradeniya, Peradeniya, Sri Lanka. ${ }^{2}$ Department of Oral Medicine and Periodontology, Faculty of Dental Sciences, University of Peradeniya, Peradeniya, Sri Lanka. ${ }^{3}$ Department of Chemistry, Faculty of Science, University of Peradeniya, Peradeniya, Sri Lanka. ${ }^{4}$ Department of Biochemistry and Clinical Chemistry, Faculty of Medicine, University of Kelaniya, Ragama, Sri Lanka. ${ }^{5}$ Department of Pathology, Faculty of Medicine, University of Kelaniya, Ragama, Sri Lanka. ${ }^{6}$ Department of Pathobiology, Faculty of Veterinary Medicine \& Animal Science, University of Peradeniya, Peradeniya, Sri Lanka. ${ }^{7}$ School of Tropical Medicine and Global Health, Nagasaki University, 1-12-4, Sakamoto, Nagasaki 852-8523, Japan.

Received: 1 September 2019 Accepted: 6 August 2020

Published online: 20 August 2020

\section{References}

1. Kassebaum NJ, Smith AGC, Bernabé E, Fleming TD, Reynolds AE, Vos T, Murray CJL. Marcenes W; GBD 2015 Oral health collaborators. Global, regional, and National Prevalence, incidence, and disability-adjusted life years for Oral conditions for 195 countries, 1990-2015: a systematic analysis for the global burden of diseases, injuries, and risk factors. J Dent Res. 2017; 96(4):380-7

2. Pihlstrom BL, Michalowicz BS, Johnson NW. Periodontal diseases. Lancet. 2005:366(9499):1809-20.

3. Belinga LEE, Ngan WB, Lemougoum D, Nlo'o ASPE, Bongue B, Ngono A, Mandengue $\mathrm{SH}$, Sembene M. Association between periodontal diseases and cardiovascular diseases in Cameroon. J Public Health Africa. 2018;9(1):761.

4. Kumar A, Sharma DS, Verma M, Lamba AK, Gupta MM, Sharma S, Perumal V. Association between periodontal disease and gestational diabetes mellitusa prospective cohort study. J Clin Periodontol. 2018. https://doi.org/10.1111/ jcpe.12902.

5. Araújo VMA, Melo IM, and Lima V. Relationship between periodontitis and rheumatoid arthritis: review of the literature. Mediat Inflamm 2015. doi.10. 1155/2015/259074.

6. World Health Organization. Global report on diabetes. 2016. https://apps. who.int/iris/bitstream/handle/10665/204871/9789241565257_eng.pdf. Accessed 17 Nov 2018.

7. Cardoso EM, Reis C, Manzanares-Cespedes MC. Chronic periodontitis, inflammatory cytokines, and interrelationship with other chronic diseases. J Postgrad Med. 2018;130(1):98-104. 
8. Holt SC, Ebersole JL. Porphyromonas gingivalis, Treponema denticola, and Tannerella forsythia: the "red complex", a prototype polybacterial pathogenic consortium in periodontitis. Periodontol 2000. 2005;38:72-122.

9. Hajishengallis G, Darveau RP, Curtis MA. The keystone-pathogen hypothesis. Nat Rev Microbiol. 2012;10(10):717-25.

10. Rafiei M, Kiani F, Sayehmiri K, Sayehmiri F, Tavirani M, Dousti M, et al. Prevalence of anaerobic Bacteria ( $P$. gingivalis) as major microbial agent in the incidence periodontal diseases by meta-analysis. J Dent. 2018;19(3): 232-42.

11. Hajishengallis G, Lamont RJ. Breaking bad: manipulation of the host response by Porphyromonas gingivalis. Eur J Immunol. 2014;44(2):328-38.

12. Bostanci N, Belibasakis GN. Porphyromonas gingivalis: an invasive and evasive opportunistic oral pathogen. FEMS Microbiol Lett. 2012;333(1):1-9.

13. Scott DA, Krauss J. Neutrophils in periodontal inflammation. Front Oral Biol. 2012;15:56-83.

14. Chapple IL, Matthews JB. The role of reactive oxygen and antioxidant species in periodontal tissue destruction. Periodontol 2000. 2007;43: $160-232$.

15. Wang Y, Andrukhov O, Rausch-Fan X. Oxidative stress and antioxidant system in periodontitis. Front Physiol. 2017;8:910.

16. Sharma S, Khan IA, Ali I, Ali F, Kumar M, Kumar A, et al. Evaluation of the antimicrobial, antioxidant, and anti-inflammatory activities of Hydroxychavicol for its potential use as an Oral care agent. Antimicrob Agents Chemother. 2009;53(1):216-22.

17. Hung YT, Hou LT, Wong MY. The effects of areca nut extract and nicotine on selected periodontal pathogens; in vitro study. Chin Dent J. 2005;24(2): $101-6$.

18. Cai L. Compounds from Syzygium aromaticum possessing growth inhibitory activity against Oral pathogens. J Nat Prod. 1996;59(10):987-90.

19. Zhang Y, Wang Y, Zhu X, Cao P, Wei S, Lu Y. Antibacterial and antibiofilm activities of eugenol from essential oil of Syzygium aromaticum (L.) Merr. \& L. M. Perry (clove) leaf against periodontal pathogen Porphyromonas gingivalis. Microb Pathog. 2017;113:396-402

20. Shafiei Z, Shuhairi NN, Md Fazly Shah Yap N, Harry Sibungkil C-A, Latip J. Antibacterial Activity of Myristica fragrans against Oral Pathogens. Evid Based Complement Alternat Med. 2012; 7 .

21. Nanasombat S, Kuncharoen N, Ritcharoon B, Sukcharoen P. Antibacterial activity of thai medicinal plant extracts against oral and gastrointestinal pathogenic bacteria and prebiotic effect on the growth of lactobacillus acidophilus. J Med Assoc Thail. 2018:33-44.

22. Bersan SM, Galvao LC, Goes VF, Sartoratto A, Figueira GM, Rehder VL, et al. Action of essential oils from Brazilian native and exotic medicinal species on oral biofilms. BMC Complement Altern Med. 2014;14:451.

23. Zhou X, Sai WS, Dennis C, Hosen K, Valentina RN, Kelvin C, Alan B. Synergistic effects of Chinese herbal medicine: a comprehensive review of methodology and current research. Front Pharmacol. 2016;201.

24. Arambewela L, Arawwawala M, Rajapaksa D. Piper betle: a potential natural antioxidant. Int J Food Sci Technol. 2006;41(1):10-4.

25. Chavan YV, Singhal RS. Separation of polyphenols and Arecoline from Areca nut (Areca Catechu L.) by solvent extraction, its anti oxidant activity, and identification of polyphenols. J Sci Food Agric. 2013;93(10):2580-9.

26. Rojas C, Francisco D, Souza CRF, Oliveira VP. Clove (Syzygium aromaticum): a precious spice. Asian Pac J Trop Biomed. 2014;2:90-6.

27. Deepa B, Anuradha CV. Antioxidant potential of Coriandrum sativum L. Seed Extract Indian J Exp Biol. 2011;49(1):30-8.

28. Sahoo S, Reena P, Sikha S, Rabindra NP, Nayak S. Evaluation of yield, quality and antioxidant activity of essential oil of in vitro propagated Kaempferia galanga Linn. J Acute Dis. 2014;3(2):124-30.

29. Gupta AD, Vipin KB, Vikash B, Nishi M. Chemistry, antioxidant and antimicrobial potential of nutmeg (Myristica fragrans Houtt). J Genet Eng Biotechnol. 2013;11(1):25-31.

30. Singh G, Shashi K, Palanisamy M, Valery I, Vera V. Antioxidant and antimicrobial activities of essential oil and various oleoresins of Elettaria cardamomum (seeds and pods). J Sci Food Agric. 2008;88(2):280-9.

31. Manach C, Scalbert A, Morand C, Remesy C, Jimenez L. Polyphenols: food sources and bioavailability. Am J Clin Nutr. 2004;79(5):727-47.

32. Terao J. 14 factors affecting bioavailability of plant polyphenols. Biochem Pharmacol. 2017;139:105-6.

33. Madduluri S, Babu Rao K, Sitaram B. In vitro evaluation of antibacterial activity of five indigenous plants extract against five bacterial pathogens of human. Int J Pharm Pharm Sci. 2013;5:679-84.
34. Gamboa F, Muñoz CC, Numpaque G, Sequeda-Castañeda LG, Gutierrez SJ, and Tellez N. Antimicrobial Activity of Piper marginatum Jaca and Ilex guayusa Loes on Microorganisms Associated with Periodontal Disease. Int. J. Microbiol.2018:1-9. doi.org/10.1155/2018/4147383.

35. CLSI, Methods for Determining Bactericidal Activity of Antimicrobial Agents. Approved Guideline, CLSI document M26-A. 1998. Clinical and Laboratory Standards Institute, 950 West Valley Roadn Suite 2500,Wayne, Pennsylvania 19087, USA..

36. Singleton VL, Rossi JA. Colorimetry of Total Phenolics with Phosphomolybdic-Phosphotungstic acid reagents. Am J Enol Vitic. 1965; 16(3):144-58.

37. Brand-Williams W, Cuvelier ME, Berset C. Use of a free radical method to evaluate antioxidant activity. Food Sci Technol. 1995;28(1):25-30.

38. Re R, Pellegrini N, Proteggente A, Pannala A, Yang M, Rice-Evans C. Antioxidant activity applying an improved ABTS radical Cation Decolorization assay. Free Radic Biol Med. 1999;26(9-10):1231-7.

39. Benzie IF, Strain JJ. The ferric reducing ability of plasma (FRAP) as a measure of antioxidant power: the Frap assay. Anal Biochem. 1996;239(1):70-6.

40. Illeperuma RP, Kim DK, Park YJ, Son HK, Kim JY, Kim J, Lee DY, Kim KY, Jung DW, Tilakaratne WM, Kim J. Areca nut exposure increases secretion of tumor-promoting cytokines in gingival fibroblasts that trigger DNA damage in oral keratinocytes. Int J Cancer. 2015;137(11):2545-57.

41. van Meerloo J, Kaspers GJ, Cloos J. Cell sensitivity assays: the MTT assay. Methods Mol Biol. 2011;731:237-45

42. Nur Sazwi N, Nalina T, Rahim ZHA. Antioxidant and cytoprotective activities of Piper betle, Areca catechu, Uncaria gambir and betel quid with and without calcium hydroxide. BMC Complement Altern Med. 2013;13(1):351.

43. Fenech M. Cytokinesis-block micronucleus Cytome assay. Nat Protoc. 2007; 2(5):1084-104.

44. U.S. Department of Health and Human Services Food and Drug Administration, Center for Drug Evaluation and Research (CDER), Center for Biologics Evaluation and Research (CBER). Guidance for Industry S2 (R1) Genotoxicity Testing and Data Interpretation for Pharmaceuticals Intended for Human Use. 2012.

45. Iwaki K, Koya-Miyata S, Kohno K, Ushio S, Fukuda S. Antimicrobial activity of Polygonum tinctorium Lour: extract against oral pathogenic bacteria. Nat Med. 2006;60:121-5.

46. Mohieldin EAM, Muddathir AM, Mitsunaga T. Inhibitory activities of selected Sudanese medicinal plants on Porphyromonas gingivalis and matrix metalloproteinase-9 and isolation of bioactive compounds from Combretum hartmannianum (Schweinf) bark. BMC Complement Altern Med. 2017;17(1):224.

47. Patra JK, Kim ES, Oh K, Kim H-J, Kim Y, Baek K-H. Antibacterial effect of crude extract and metabolites of Phytolacca americana on pathogens responsible for periodontal inflammatory diseases and dental caries. BMC Complement Altern Med. 2014;14:343-.

48. Araghizadeh A, Kohanteb J, Fani MM. Inhibitory activity of green tea (Camellia sinensis) extract on some clinically isolated cariogenic and Periodontopathic Bacteria. Med Prin Pract. 2013;22(4):368-72.

49. Shetty S, Thomas B, Shetty $V$, Bhandary R, Shetty RM. An in-vitro evaluation of the efficacy of garlic extract as an antimicrobial agent on periodontal pathogens: a microbiological study. Ayu. 2013;34(4):445-51.

50. Herrera Herrera A, Franco Ospina L, Fang L, Díaz Caballero A. Susceptibility of Porphyromonas gingivalis and Streptococcus mutans to Antibacterial Effect from Mammea americana. Adv Pharmacol Sci. 2014; 2014:384815-.

51. Gao Y, Zhang X, Yin J, Du Q, Tu Y, Shi J, et al. Castanopsis lamontii water extract shows potential in suppressing pathogens, lipopolysaccharideinduced inflammation and oxidative stress-induced cell injury. Molecules. 2019;24(2):273.

52. Kohli D, Hugar S, Bhat K, Shah P, Mundada M, Badakar C. Comparative evaluation of the antimicrobial susceptibility and cytotoxicity of husk extract of Cocos nucifera and chlorhexidine as irrigating solutions against Enterococcus Faecalis, Prevotella Intermedia and Porphyromonas Gingivalis An in-vitro study. J Indian Soc Pedod Prev Dent. 2018;36:142.

53. Kasote DM, Katyare SS, Hegde MV, Bae H. Significance of antioxidant potential of plants and its relevance to therapeutic applications. Int J Biol Sci. 2015:11(8):982-91.

54. Alam MN, Bristi NJ, Rafiquzzaman M. Review on in vivo and in vitro methods evaluation of antioxidant activity. Saudi Pharm J. 2013;21(2):143-52.

55. Hwang KA, Hwang YJ, Song J. Antioxidant activities and oxidative stress inhibitory effects of ethanol extracts from Cornus officinalis on raw 264.7 cells. BMC Complement Altern Med. 2016; 16:196- 
56. Pandey KB, Rizvi SI. Plant polyphenols as dietary antioxidants in human health and disease. Oxidative Med Cell Longev. 2009;2(5):270-8.

57. Msaada K, Jemia MB, Salem N, Bachrouch O, Sriti J, Tammar S, Bettaieb I, Jabri I, Kefi S, Limam F, Marzouk B. Antioxidant activity of methanolic extracts from three coriander (Coriandrum sativum L.) fruit varieties. Arab J Chem. 2017;10(2):S3176-83.

58. Sultana S, Ripa FA, Hamid K. Comparative antioxidant activity study of some commonly used spices in Bangladesh. Paki J Biol Sci. 2010;13:340-3.

59. Tuekaew J, Siriwatanametanon N, Wongkrajang Y, Temsiririrkkul R, Jantan I. Evaluation of the antioxidant activities of Ya-hom Intajak, a Thai herbal formulation, and its component plants. Trop J Pharm Res. 2014;13(9): 1477-85.

60. Chan E, Lim Y, Wong LF, Lianto FS, Wong SK, Lim KK, Joe CE, Lim TY. Antioxidant and Tyrosinase inhibition properties of leaves and rhizomes of ginger species. Food Chem. 2008;109:477-83.

61. Burger RM. Cleavage of nucleic acids by Bleomycin. Chem Rev. 1998;98(3): 1153-70.

62. Cho YH, Lee JW, Woo HD, Lee S, Kim YJ, Lee Y, et al. Protective effect of onion extract on Bleomycin-induced cytotoxicity and Genotoxicity in human lymphocytes. Int J Environ Res Public Health. 2016;13(2):227. https:// doi.org/10.3390/ijerph13020227.

63. Galhena BP, Samarakoon SSR, Thabrew MI, Solomon FDP, Perumal V, and Mani C. Protective Effect of a Polyherbal Aqueous Extract Comprised of Nigella sativa (Seeds), Hemidesmus indicus (Roots), and Smilax glabra (Rhizome) on Bleomycin Induced Cytogenetic Damage in Human Lymphocytes. BioMed Res Int. 2017; doi. /10.1155/2017/1856713.

64. Shirname LP, Menon MM, Bhide SV. Mutagenicity of betel quid and its ingredients using mammalian test systems. Carcinogenesis. 1984;5(4): 501-3.4.

65. Chen PH, Mahmood Q, Mariottini GL, Chiang TA, Lee KW. Adverse Health Effects of Betel Quid and the Risk of Oral and Pharyngeal Cancers. BioMed Res Int. 2017; doi.org/10.1155/2017/3904098.

66. Chiba I. Prevention of betel quid chewers' Oral Cancer in the Asian-Pacific area. Asian Pac J Cancer Prev. 2001:2:263-9.

67. Lee $\mathrm{CH}$, Ko AM, Warnakulasuriya S, Yin BL. Sunarjo, Zain RB, Ibrahim SO, Liu ZW, Li WH, Zhang SS, Kuntoro, Utomo B, Rajapakse PS, Warusavithana SA, Razak, IA, Abdullah N, Shrestha P, Kwan AL, Shieh TY, Chen MK. Ko YC. Et al. Intercountry prevalences and practices of betel-quid use in south, southeast and eastern Asia regions and associated oral preneoplastic disorders: an international collaborative study by Asian betel-quid consortium of south and East Asia. Int J Cancer. 2011;129(7):1741-51.

68. IARC Working Group on the Evaluation of Carcinogenic Risks to Humans Betel-quid and areca-nut chewing and some areca-nut derived nitrosamines. IARC Monogr. Eval Carcinog Risks Hum. 2004, 85, 1-334.

69. Thomas SJ, MacLennan R. Slaked lime and betel nut cancer in Papua New Guinea. Lancet. 1992;340(8819):577-8.

70. Nair UJ, Obe G, Friesen M, Goldberg MT, Bartsch H. Role of lime in the generation of reactive oxygen species from betel-quid ingredients. Environ Health Perspect. 1992;98:203-5.

71. Amarasinghe HK, Usgodaarachchi US, Johnson NW, Lalloo R, Warnakulasuriya S. Betel-quid chewing with or without tobacco is a major risk factor for oral potentially malignant disorders in Sri Lanka: a case-control study. Oral Oncol. 2010;46(4):297-301.

72. Li YC, Cheng AJ, Lee LY, Huang YC, Chang JTC. Multifaceted mechanisms of Areca nuts in Oral carcinogenesis: the molecular pathology from precancerous condition to malignant transformation. J Cancer. 2019;10(17):4054-62.

73. Lu CT, Yen YY, Ho CS, Ko YC, Tsai CC, Hsieh CC, et al. A case-control study of oral cancer in Changhua County. Taiwan Journal Oral Pathol Med. 1996; 25(5):245-8.

74. Jeong SJ, Kim OS, Yoo SR, Seo CS, Kim Y, Shin HK. Anti-inflammatory and antioxidant activity of the traditional herbal formula Gwakhyangjeonggi-san via enhancement of heme oxygenase-1 expression in RAW264.7 macrophages. Mol Med Rep. 2016;13(5):4365-71.

75. Liu YJ, Peng W, Hu MB, Xu M, Wu CJ. The pharmacology, toxicology and potential applications of arecoline: a review. Pharm Biol. 2016;54(11):2753-60.

76. Peng W, Liu YJ, Hu MB, Yan D, Gao YX, Wu CJ. Using the "target constituent removal combined with bioactivity assay" strategy to investigate the optimum arecoline content in charred areca nut. Sci Rep. 2017;7(1):40278.

77. Cheng HL, Su SJ, Huang LW, Hsieh BS, Hu YC, Hung TC, et al. Arecoline induces HA22TNGH hepatoma cells to undergo anoikis - involvement of STAT3 and RhoA activation. Mol Cancer. 2010;9(1):126.
78. Fan J, Lin R, Xia S, Chen D, Elf SE, Liu S, et al. Tetrameric acetyl-CoA Acetyltransferase 1 is important for tumor growth. Mol Cell. 2016;64(5):859-74.

79. Tariot PN, Cohen RM, Welkowitz JA, Sunderland T, Newhouse PA, Murphy $\mathrm{DL}$, et al. Multiple-dose Arecoline infusions in Alzheimer's disease. Arch Gen Psychiatry. 1988;45(10):901-5.

80. Xu Z, Adilijiang A, Wang W, You P, Lin D, Li X, et al. Arecoline attenuates memory impairment and demyelination in a cuprizone-induced mouse model of schizophrenia. Neuroreport. 2019;30(2):134-8.

81. Illeperuma DR, Bandara MK, Kim DDK, Siriwardena PS, Jayasinghe PR, Kim PJ, et al. Antioxidant rich tropical herbs to combat Areca-nut induced OPMDs. Oral Surg Oral Med Oral Pathol Oral Radiol. 2019;128(1):e80-e1.

82. Zhou J, Sun Q, Yang Z, Zhang J. The hepatotoxicity and testicular toxicity induced by arecoline in mice and protective effects of vitamins $C$ and $E$. Korean J Physiol Pharmacol. 2014;18(2):143-8.

83. Padma PR, Amonkar AJ, Bhide SV. Antimutagenic effects of betel leaf extract against the mutagenicity of two tobacco-specific $\mathrm{N}$-nitrosamines. Mutagenesis. 1989;4(2):154-6.

84. Dwivedi V, Shrivastava R, Hussain S, Ganguly C, Bharadwaj M. Comparative anticancer potential of clove (Syzygium aromaticum)-an Indian spice against cancer cell lines of various anatomical origin. Asian Pac J Cancer Prev. 2011; 12(8):1989-93.

85. Tang EL, Rajarajeswaran J, Fung SY, Kanthimathi MS. Antioxidant activity of Coriandrum sativum and protection against DNA damage and cancer cell migration. BMC Complement Altern Med. 2013;13:347.

86. Elguindy NM, Yacout GA, El Azab EF, Maghraby HK. Chemoprotective effect of Elettaria Cardamomum against chemically induced hepatocellular carcinoma in rats by inhibiting NF-kB, oxidative stress, and activity of ornithine decarboxylase. S Afr J Bot. 2016;105:251-8.

87. Ichwan SJA, Husin A, Suriyah WH, Lestari W, Omar MN, Kasmuri AR. Antineoplastic potential of ethyl-p-methoxycinnamate of Kaempferia galanga on oral cancer cell lines. Materials Today: Proceedings. 2019;16:2115-21.

88. Kim EY, Choi HJ, Park MJ, Jung YS, Lee SO, Kim KJ, et al. Myristica fragrans suppresses tumor growth and metabolism by inhibiting lactate dehydrogenase a. Am J Chinese Med. 2016;44(05):1063-79.

\section{Publisher's Note}

Springer Nature remains neutral with regard to jurisdictional claims in published maps and institutional affiliations.
Ready to submit your research? Choose BMC and benefit from:

- fast, convenient online submission

- thorough peer review by experienced researchers in your field

- rapid publication on acceptance

- support for research data, including large and complex data types

- gold Open Access which fosters wider collaboration and increased citations

- maximum visibility for your research: over $100 \mathrm{M}$ website views per year

At $\mathrm{BMC}$, research is always in progress.

Learn more biomedcentral.com/submissions 